Egyptian Journal of Aquatic Biology \& Fisheries

Zoology Department, Faculty of Science,

Ain Shams University, Cairo, Egypt.

ISSN $1110-6131$

Vol. 25(3): 831-840 (2021)

www.ejabf.journals.ekb.eg

\title{
Toxicity of Anthracene on the Function of the Liver and Kidney of the Common Carp Cyprinus carpio
}

\author{
Estabraq N. Abdul Lateef*, Milad A. Hussein „Sarab R. Mustafa, Maha M. Taen, \\ Suha A. Ali and Nora Saheab \\ Ministry of Science and Technology, Environment and Water Director, Baghdad, Iraq \\ *Corresponding Author: estbionabeel86@gmail.com
}

\section{ARTICLE INFO \\ Article History: \\ Received:June 12, 2021 \\ Accepted: June 26, 2021 \\ Online: June 30, 2021}

Keywords:

PAH,

Anthracene,

Liver enzyme,

Kidney function,

Common carp.

\section{ABSTRACT}

Anthracene, composed of three-ringed polycyclic aromatic hydrocarbon, is a widely known hazardous ubiquitous environmental pollutant. Anthracene is used to make dyes, plastics, and pesticides. The study aimed to estimate the effects of anthracene on liver and kidney functions of common carp. Ninety fishes were adapted and acclimated to the laboratory conditions for one week before starting the experiment, then they were exposed to $(7.5 \mathrm{mg} / \mathrm{L}, 10 \mathrm{mg} / \mathrm{L}$, $12.5 \mathrm{mg} / \mathrm{L}$ ) of anthracene for 72 hours. Results demonstrated that the $\mathrm{LD}_{50}$ of anthracene in fish was $(10 \mathrm{mg} / \mathrm{L})$ according to the $\mathrm{LC}_{50}$ values. Fish were then exposed to three sub-lethal concentrations of the anthracene $(2.5 \mathrm{mg} / \mathrm{L}, 5 \mathrm{mg} / \mathrm{L}$ and $7.5 \mathrm{mg} / \mathrm{L}$ ) and a control with $0.00 \mathrm{mg} / \mathrm{L}$. Afterwards ( 72 hours, 10 days, 20 days) fishes were sacrificed to take the kidney and liver to estimate the organs' function. The liver enzymes (AST, ALT and ALP) assessed were higher than the control group values. The higher recorded average of ALT was 26.87 (U/L) after exposure to anthracene $(7.5 \mathrm{mg} / \mathrm{L})$, while the lowest average of ALT in the control group was $4.64(\mathrm{U} / \mathrm{L})$. Moreover, the lowest average of AST was 4.09 $(\mathrm{U} / \mathrm{L})$ in the control group, whereas the highest average was $27.58(\mathrm{U} / \mathrm{L})$ after exposure to anthracene $(7.5 \mathrm{mg} / \mathrm{L})$. For ALP, the lowest average was $4.54(\mathrm{U} / \mathrm{L})$ in the control group while the highest was 18.52 (U/L) after exposure to anthracene $(7.5 \mathrm{mg} / \mathrm{L})$. In addition, creatinine and urea levels in kidney tissue showed a significant increase when compared to the control group. The highest average of creatinine recorded was $0.83 \mathrm{mg} / \mathrm{dL}$ in the group treated with 7.5 $\mathrm{mg} / \mathrm{L}$ and the lowest average was $0.14 \mathrm{mg} / \mathrm{dl}$ in the control group. On the other hand, the highest average of urea recorded was $21.48 \mathrm{mg} / \mathrm{dl}$ in the group treated with $7.5 \mathrm{mg} / \mathrm{L}$, while the lowest average was $8.66 \mathrm{mg} / \mathrm{dl}$ in the control group. This study concluded that the anthracene has a toxic effect on the liver and kidney of the common carp.

\section{INTRODUCTION}

Polycyclic aromatic hydrocarbons (PAHs) are a part of organic pollutants which contain two or more fused aromatic rings composed of carbon and hydrogen. Naphthalene is the simplest PAH, consisting of two aromatic benzene rings. Phenanthrene and anthracene are three-ringed compounds, the number of possible structures are multiplies with the increasing of ring number (Collier $\boldsymbol{e t}$ al., 2013). PAHs are widely present in the 
drinking water, air and food. Inspiration of particle borne or gaseous polycyclic aromatic hydrocarbons happens during automobile exhausts, tobacco smoke and burning processes such as burning of biomass, oil, and coal. Manufactories where exposure to polycyclic aromatic hydrocarbons is possible to happen include coal tar use, steel and iron works, foundries, coke ovens, asphalt manufacture, carbon electrode aluminum works, and carbon black manufacture...etc. The unprofessional exposure to polycyclic aromatic hydrocarbons for a non-smoking individual can be related with food system, mainly vegetables, grains and cooked food specially barbecued meat which cooked on open flame (Issa \& El-Sherif, 2015).

The exposure to high levels and several occupations of pollutants containing polycyclic aromatic hydrocarbons lead to many symptoms such as vomiting, diarrhea, nausea, eye irritation, skin inflammation. Anthracene, naphthalene and benzo(a)pyrene cause direct skin irritation while benzo(a)pyrene and anthracene in skin sensitizers lead to an skin allergy for both humans and animals. Many healthy problems (an increased hazard of bladder, gastrointestinal, lung and skin cancer) that workers suffer from are related to their expoture to a mixture of polycyclic aromatic hydrocarbons and PAH chemicals, PAH (e.g. PyreneandBaP) has been classified as the reason of cancers in animal laboratory. Expoture to PAH induces DNA damage; a danger that has been recorded by numerous authors. Continuously exposed to polycyclic aromatic hydrocarbons is suspected to increase the risks of cell damage by cardiopulmonary mortality and gene mutation (Lawal, 2017).

Anthracene is one of the PAH chosen for the current study because of its relative toxicity. It is a solid polycyclic aromatic hydrocarbon and it can alter its coloring appearance from uncolored to pale yellow crystals. Limited information has been found with respect to humans subjected to such pollutants to address the effects of exposure to PAHs at particular levels. Skin contact and inhalation of PAHs seem to be associated with cancer in humans (Tarafdar \& Sinha, 2015). The increasing levels of contamination in aquatic ecosystems due to chemical monitoring programs worldwide has been documented. The coastal environments are continuously exposed to varied chemical pollution, derived from offshore oil spill, agricultural and industrial runoff or discharge of household wastes (Asnicaret al., 2018).

The developments of industries and growth of human population have led to high levels of water pollution forming a dangerous threat to different aquatic ecosystems. Fish are a good design to study the carcinogenic and/or mutagenic capacity of contaminants present in water since they can concentrate, metabolize and store water borne pollutants. Fish can be used to detect chemicals that are potentially carcinogenic and teratogenic in humans since they respond to toxicants in a way similar to higher vertebrates (Kumar, 2012). 
Fish liver is the essential organ of necessary metabolic reactions including lipids, protein and carbohydrate, besides its role of detoxification. Moreover, liver stores glucose and vitamins of E, K, B12, D and A (Mitra \& Metcalf, 2009).

Alkaline phosphatase (ALP), Transaminase enzymes, including aspartate transferase (AST), alanine transferase (ALT) are necessary for protein and amino acid metabolism in tissues of fish. They are key metabolic enzymes released into the blood from damaged liver cells that have elevated synthesis due to induction. Hepatocytes' damages are determined in accordance to the changes in plasma levels of transaminase enzymes (Jagadeesan \& Kavitha, 2006).

The muscles produce a waste product called creatinine when they break down a compound called creatine, which helps contract the muscles, is released. Creatinine is a substance the body produces during normal metabolism. The body eliminates creatinine almost exclusively through the kidney filtration process, thus, measurement of creatinine is an accurate estimation of how well the kidney filtration process is working. Urea (Blood urea nitrogen) test measuresthe amount of nitrogen in the blood that comes from the waste product urea; urea is made when protein is broken down in the body (Ajeniyi \& Solomon, 2014). This study was conducted to explain the effects of anthracene on kidney (Creatinine, urea) and liver (ALT, AST and ALP) of common carp exposed to anthracene.

\section{MATERIALS AND METHODS}

\section{Test Species}

A total of 90 fish of common carp (Cyprinus carpio), with lengths ranging between 7-9 $\mathrm{cm}$ and weight of 60-80 gm, with no visible signs of disease or morbidity were collected for examination. Fish were fed on commercial feed in aquarium with aerated tap water and adapted to laboratory conditions for one week before the experiments were applied as shown in Fig. (1).

\section{Experimental design}

The fish were kept in 20L aquarium and smooth aerated tap water. Each group containing 10 fish specimens were randomly exposed to anthracene concentrations $(7.5,10.0$ and $12.5 \mathrm{mg} / \mathrm{L}$ ), then after $72 \mathrm{~h}$, the $\mathrm{LC}_{50}$ value of anthracene for $C$. carpio was determined as $10.0 \mathrm{mg} / \mathrm{L}$. According to the $\mathrm{LC}_{50}$ value, the fish under study were then exposed for $72 \mathrm{~h}$ to three sub-lethal concentrations of anthracene $(2.5 \mathrm{mg} / \mathrm{L}, 5 \mathrm{mg} / \mathrm{L}$ and $7.5 \mathrm{mg} / \mathrm{L})$ with a control group $(0.00 \mathrm{mg} / \mathrm{L})$ that was set for comparison. No mortalities occurred in all groups after the exposure period. After $72 \mathrm{~h}$ (Acute exposure) fish were sacrificed to extract liver and kidney from each fish. Furthermore, every 10 days of the 3 weeks experimental period, the extraction operation was achieved to estimate liver and kidney functions. 


\section{Biochemical Analysis}

Liver and kidney tissue extracts were saved in small glass containers at $-20^{\circ} \mathrm{C}$ to measure the level of enzymes of aspartate aminotransferase (AST), alanine aminotransferase (ALT), and alkaline phosphatase (ALP) in liver, as well as creatinine and urea in kidney. In addition, the kidney and liver were washed with saline and homogenized at a ratio of 1 to10 from phosphate buffer and then centrifuged at $12000 \mathrm{~g}$ for $15 \mathrm{~min}$ (Dai et al., 2009). The aforementioned enzymes were measured by using a commercial kit (the work steps for measuring ALT, AST, ALP, creatinine and urea were according to the instructions of the manufacturer of the kit).

For the statistical analysis, the use of SPSS software was implemented. A comparison was held between the treated groups and the untreated one in different days by using of one-way ANOVA and separated in case of extensive variations by using Duncan's test. The diagrams was drawn using Excel software (Excel 2010) based totally on common and standard error.

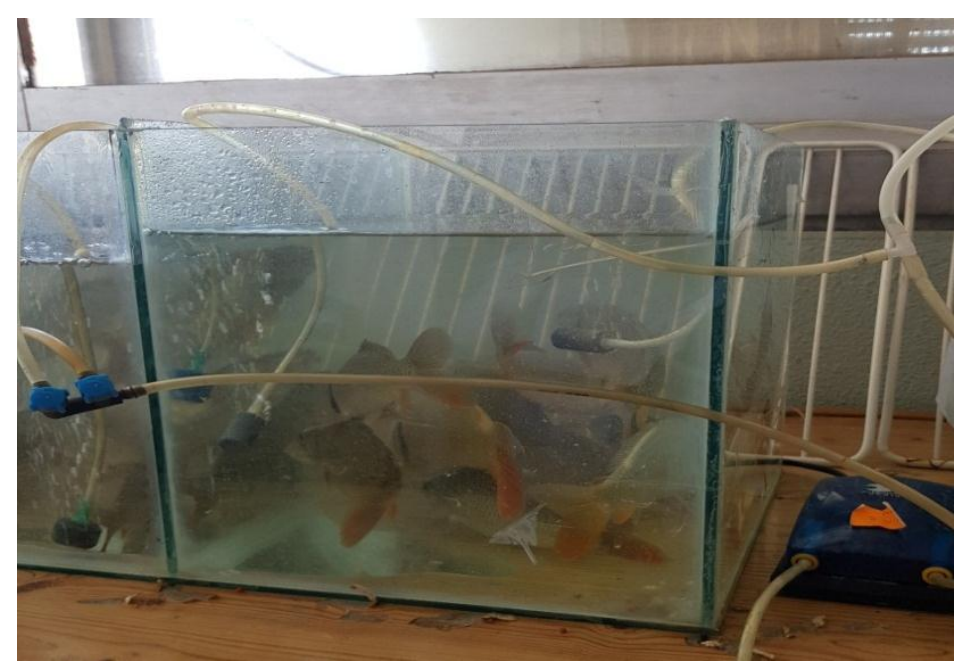

Fig. 1: Aquarium with Aerated Tap Water, where Fish are Kept.

\section{RESULTS}

The levels of ALT enzymes in the liver of fish at different concentrations of anthracene are significantly different when compared to the control group at different times ( $\mathrm{p}<0.05)$. The lowest value of ALT observed was $\pm 4.64(\mathrm{U} / \mathrm{L})$ in the control group, while \pm 12.42 (U/L) was detected after exposure to anthracene $(2.5 \mathrm{mg} / \mathrm{L}), \pm 19.89(\mathrm{U} / \mathrm{L})$ was estimated after exposure to anthracene $(5 \mathrm{mg} / \mathrm{L})$, and \pm 26.87 (U/L) was recorded after exposure to anthracene $(7.5 \mathrm{mg} / \mathrm{L}$ ) in the liver tissue, respectively (Fig. 2). Remarkably, the AST levels increased with increasing concentration of anthracene in different periods. The lowest AST levels were recorded as follows: \pm 4.09 (U/L) in the control group, \pm 12.12 (U/L) after exposure to anthracene $(2.5 \mathrm{mg} / \mathrm{L}), \pm 20.50$ (U/L) after exposure to 
anthracene $(5 \mathrm{mg} / \mathrm{L})$ and \pm 27.58 (U/L) after exposure to anthracene $(7.5 \mathrm{mg} / \mathrm{L})$ in the liver tissue, respectively as shown in Fig. (2). The amount of ALP in the liver of fish showed a significant difference between the different concentrations of anthracene and the control group ( $\mathrm{p}<0.05$ ). Additionally, the lowest amount of ALP was $\pm 4.54(\mathrm{U} / \mathrm{L})$ in the control group, \pm 10.60 (U/L) after exposure to anthracene $(2.5 \mathrm{mg} / \mathrm{L}), \pm 15.42$ (U/L) after exposure to anthracene $(5 \mathrm{mg} / \mathrm{L})$ and \pm 18.52 (U/L) after exposure to anthracene $(7.5 \mathrm{mg} / \mathrm{L})$ in the liver tissue, respectively as presented in Fig. (2).

In the present study, fish treated with three sub-lethal concentrations of the anthracene $(2.5,5$ and $7.5 \mathrm{mg} / \mathrm{L})$ showed increased levels of creatinine with increasing concentration of anthracene in different periods. It was noticed that, the highest level of creatinine was $\pm 0.83 \mathrm{mg} / \mathrm{dL}$ in group treated with $7.5 \mathrm{mg} / \mathrm{L}$, and the lowest level was $\pm 0.14 \mathrm{mg} / \mathrm{dl}$ in control group as shown in Fig. (3). It is worthnoting that, creatinine increases as kidney function decreases.

In addition, the levels of urea in the kidney of fish at different concentrations of anthracene were significantly different when compared to the control group at different times ( $\mathrm{p}<0.05$ ). The highest level of urea recorded was $\pm 21.48 \mathrm{mg} / \mathrm{dl}$ in group treated with $7.5 \mathrm{mg} / \mathrm{L}$, and the lowest level was $\pm 8.66 \mathrm{mg} / \mathrm{dl}$ in the control group (Fig. 3). Notably, the increase of creatinine and urea levels are related to the changes in cell and tissue damage. 


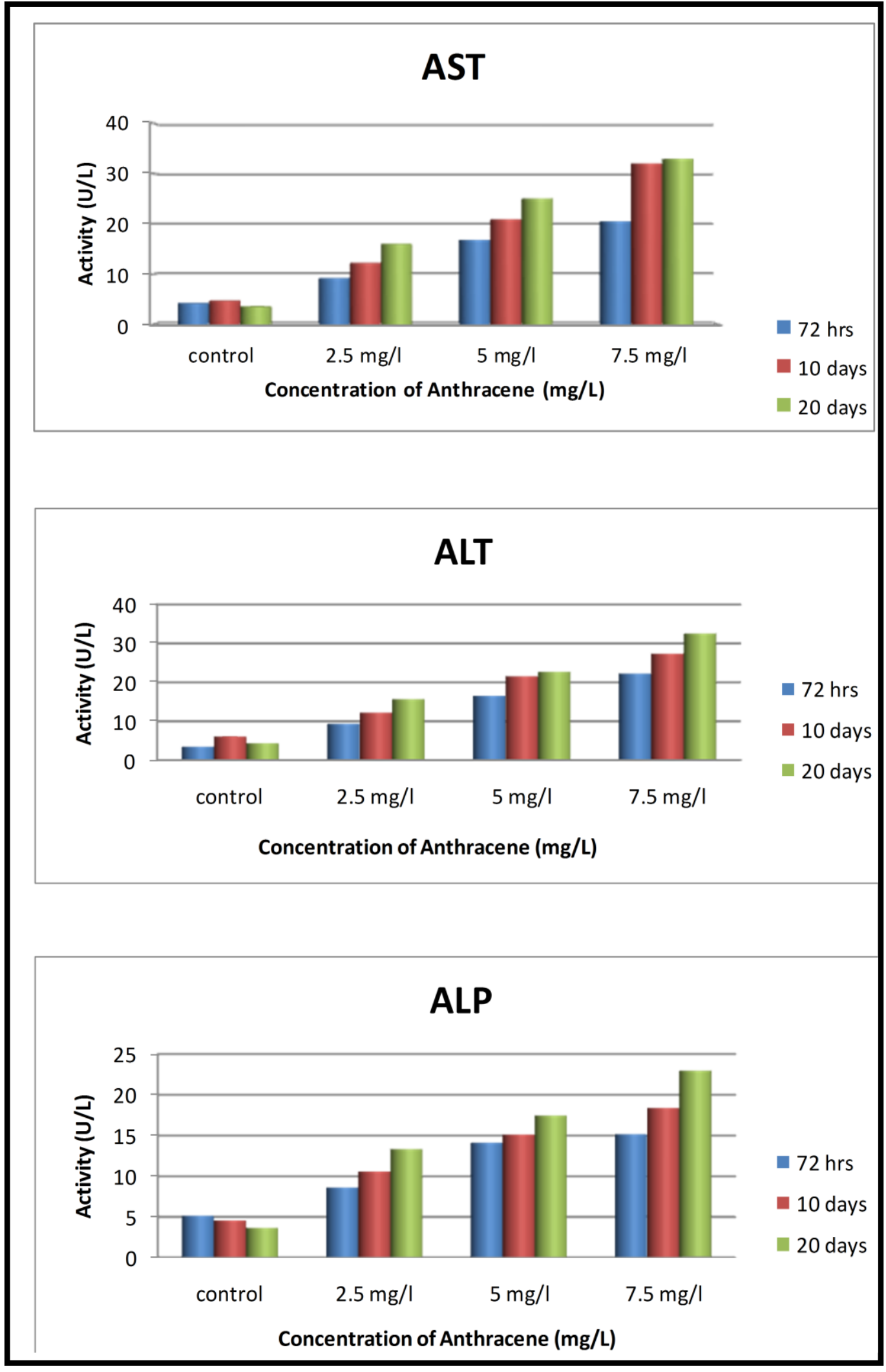

Fig. 2:The Average of ALT, AST and ALP Enzymes (U/L) in the Tissue of Liver in Different Times and Different Concentrations of Anthracene (mg/L) (One-way ANOVA-Duncan test, $\mathrm{p}<0.05)$. 


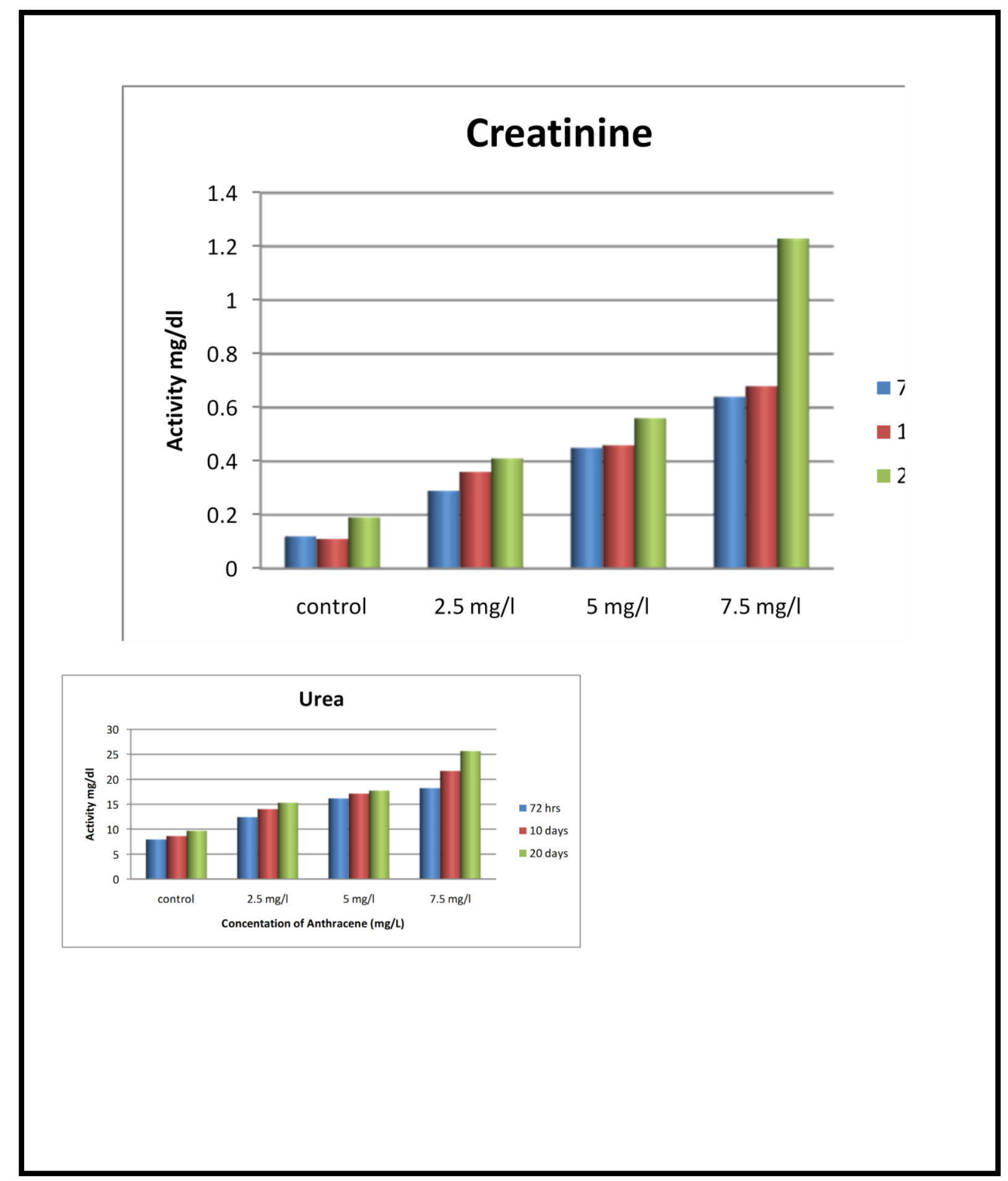

Fig. 3: The Average Levels of Ceatinine and Urea (mg/dl) in the Tissue of Kidney in Different Times and Different Concentrations of Anthracene (mg/L)(One-way ANOVA-Duncan test, $\mathrm{p}<0.05$ ). 


\section{DISCUSSION}

Many environmental stressors affect the livers and cause structural damage and metabolic disorders, and may probably lead to death. Almost the different cellular levels such as (histopathological, morphological, physiological, biochemical, cellular, and molecular), exposure, susceptibility and effective biomarkers can be used to observe initiative indicators of contamination, in addition to the healthy liver as a defensive organ against pollution difficulties (Brusle \& Anadon, 1996).

Alkaline phosphatases are very important biomarkers for cellular responses to genetic and cells toxicity (Lohneret al., 2001). Changes were identified ALP levels in organs, blood and tissues of fish when exposed to pollutants. This enzyme alteration was heavily reported and traced in the blood and body of fish when exposed to poisons. Addingly, ALP has a necessary function in the transfer of metabolites through the cell membrane and carboxylic acid cycle (TCA) to produce energy (El-Demerdash \& Elagamy, 1999; Das et al., 2004). Obviously, the increase in AST and ALT levels to produce more energy through stressful condition is due to high need and precursor of carbohydrate to maintain the glycolytic (glycolytic pathway) and constant levels of tolerance in the TCA cycle (Begum, 2005). On the other hand, the increase in the levels of ALT, AST and ALP enzymes in tissues can be viewed as an indicator of tissues damage to produce energy (Atli et al., 2006). The present study showed similar results with those of Vasanth $\boldsymbol{e t}$ al. (2012).

Eminently, fish livers have been a study target to examine the reactions that occurred between environmental factors and the structures and functions of the livers. Fish are able to absorb pollutants through the alimentary tract gill and skin mucosa. They are transported through ion channel or specialized transporter methods in the plasma membrane into the body, then into the kidney and liver (detoxification organs) when they are absorbed without accreditation of their concentration (Ardeshiret al., 2017).

\section{CONCLUSION}

Fish are excellent subjects to study the carcinogenic and mutagenic potential of pollutants present in water samples since they can concentrate, metabolize and store water born and contaminants. The results revealed that anthracene has the potential to cause changes in the levels of enzymes in kidney and liver, that are likely to cause tissue damage in fish. Hence, the ALT, AST, ALP, ceatinine and urea are recommended to be used to observe the physiological status of lives and signals of stress. 


\section{REFERENCES}

Ajeniyi, S. A. and Solomo, R. J. (2014).Urea and Creatinine of ClariasGariepinus in Three Different Commercial Ponds.Nature and Science. 12(10):124-138.

Asnicar, D.; Ašmonait e, G.; Birgersson, L.; Kvarnemo, C.; Svensson, O. and Sturve.J. (2018). Sand Goby-An Ecologically Relevant Species for Behavioural Ecotoxicology. Fishes. 3(13): 1-18.

Atli, G.; Alptekin, Ö.;Tükel, S. and Canli, M.(2006). Response of catalase activity to $\mathrm{Ag}+, \mathrm{Cd} 2+, \mathrm{Cr} 6+, \mathrm{Cu} 2+$ and $\mathrm{Zn} 2+$ in five tissues of freshwater fish, Oreochromisniloticus. Comparative Biology and Physiology.143: 218-224.

Begum, G. (2005). In vivo biochemical changes in liver and gill of Clariasbatrachus during cypermethrin exposure and following cessation of exposure. Pesticide Biochemistry and Physiology.82: 185-196.

Brusle, J. and Anadon, G. (1996). The structure and function of fish liver. In: Munshi JSD and Dutta HM, editors. Fish morphology. Boston: Massachusetts. 77-93

Collier, T. K.; Anulacion, B. F.; Arkoosh, M. R.; Dietrich, J. P.; Incardona, J. P.; Johnson, L. L.; Ylitalo, G. M. and Myers, M. S. (2013).Effects on fish of polycyclic aromatic hydrocarbons (PAHS) and naphthenic acid exposures.Organic Chemical Toxicology of Fishes. 33: 195-255.

Dai, W., Fu, L., Du, H., Jin, C. and Xu, Z. (2009). Changes in growth performance, metabolic enzyme activities, and content of $\mathrm{Fe}, \mathrm{Cu}$, and $\mathrm{Zn}$ in liver and kidney of tilapia (Oreochromisniloticus) exposed to dietary $\mathrm{Pb}$. Biological Trace Element Research, 128: 176-183.

Das, P.C.; Ayyappan, S.; Das, B.K. and Jena. J. K.(2004). Nitrite toxicity in Indian major carps: sublethal effect on selected enzymes in fingerlings of CatlacatlaLabeorohita, and Cirrhinosmrigala. Comparative Biology and Physiology, 138: 3-10.

El-Demerdash, F.M. and Elagamy, E.I. (1999). Biological effects in Tilapia nilotica fish as indicators of pollution by cadmium and mercury. International Journal of Environmental Research, 9: 173-186.

Issa, N. M. and El-Sherif, N. M. (2015). Histological and Immunohistochemical Study on the Toxic Effects of Anthracene on the lung and liver of Adult Male Albino 
Rats and the Possible Protective Role of Ocimumgratissimum Extract. Journal of Cell Biology and Histology. 1(1): 1-8

Jagadeesan, G. and Kavitha, A.V. (2006). Recovery of phosphatase and transaminase activity of mercury intoxicated Musmusculus (Linn.) liver tissue by Tribulusterrestris (Linn.) (Zygophyllaceae) extract. Tropical Biomedicine. 23(1): 4551.

Kumar, S. P. (2012). Micronucleus assay: a sensitive indicator for aquatic pollution. International Journal of Research in BioSciences. 1(2): 32-37.

Lawal, A. T. (2017).Enviromental Chemistry, Pollution \& Waste Management Review Article. Polycyclic aromatic hydrocarbons. A review. Cogent Environmental Science. 1-89.

Lohner, T. W.;Reash, R. J. and Williams, M. (2001). Assessment of tolerant sunfish populations (Lepomis spp.) inhabiting selenium-laden coal ash effluent. 2. Tissue biochemistry evaluation. Ecotoxicology Environmental Safety.50: 217-224.

Ma, J.; Liu, Y. and He, H. (2010) Degradation kinetics of anthracene by ozone on mineral oxides. Atmospheric Environment. 44 : 4446-4453.

Mitra, V. and Metcalf, J. (2009). Metabolic functions of the liver. Anaesth Intensive Care Med. 10(7):334-335.

Tarafdar, A. and Sinha A. (2015). Remediation of Anthracene: A short comparative study on Biological and Physicochemical approach. 226-231.

Vasanth, S.; Ganesh1, A.; Vijayakumar1, T. S.; Karthikeyeni1, S.; Manimegalai2, M. and Subramanian, P. (2012). Assessment of anthracene on hepatic and antioxidant enzyme activities in Labeorohita (Hamilton, 1822)Int. J. of Pharm. \& Life Sci. (IJPLS). 3(5): 1696-1704. 